\title{
„Učitelstvo zakousnuté do pokroku“: reakce Věstníku katolického učitelstva československého na školské reformy za první Československé republiky
}

\author{
Radim ŠIRL
}

\author{
ARTICLE INFO \\ Article history: \\ Received 1 March 2020 \\ Accepted 24 September \\ 2020 \\ Available online 31 \\ December 2020 \\ Keywords: \\ Bulletin of Catholic \\ Teachers, Catholicism, \\ Pedagogy, Education, \\ Pragmatism, John \\ Dewey, Václav Př́hoda, \\ the so-called Př́ihoda's \\ reform \\ R. Širl \\ Univerzita Karlova \\ Filozofická fakulta \\ katedra pedagogiky • \\ nám. J. Palacha 2 \\ 11638 Praha 1 • \\ Česká republika • \\ radim.sirl@seznam.cz
}

\begin{abstract}
"Aggressively progressive teachers": The Bulletin

of Czechoslovak Catholic Teachers and its response to the introduction of school reforms during the First Czechoslovak Republic

This study focuses on the perspective of the Czechoslovak periodical Věstnik katolického učitelstva československého (The Bulletin of Czechoslovak Catholic Teachers) on the new reform of the school system introduced during at the end of the 1920s by Václav Príhoda, who was the leading figure of such changes. Authors connected to this periodical took a quite strong stance on this issue and criticized the introduced reform in many ways and on many levels. The aim of this study is to create an overview of the most relevant and frequent opinions presented by the authors during the years 1928-1935 and to try to find common threads and themes of their positions. This includes providing a historical, pedagogical and religious context of the newly formed Czechoslovak Republic.
\end{abstract}

Povalit ohrady, jež zužovaly obzor a způsobovaly tmu ve zracich, aby zazáŕilo zacloněné slunce Virry, Naděje a Lásky na ubohé davy a aby se rozpršsel déšt' milostí do srdcí dosud vzdorujicich! Shodit šupiny z očí! A prostředek prostý: Ukazovat, že mnohá věda neni vědou, mnohé zásady a pravdy ničím jiným než dýmem, domněnkami a frázemi.

\section{Úvod}

Bohumil Boček

V následující studii se budu zabývat př́istupem autorů periodika Věstník katolického učitelstva československého vydávaným Řišským svazem katolického učitelstva československého ${ }^{1}$

\footnotetext{
${ }^{1}$ Dále jen jako Věstník; při citacích bude pro lepší přehlednost vždy uváděn postupně rok, ročník a číslo. Věstnik katolického učitelstva československého: orgán Říšského svazu katolického učitelstva československého, Praha: Svaz křest’anského učitelstva, 1923-1941.
} 
k reformním snahám ve školství na konci dvacátých a začátku třicátých let dvacátého století. Jedním z hlavních proponentů těchto snah byl Václav Příhoda (1889-1979), odborný poradce na tehdejším Ministerstvu školství a národní osvěty (MŠANO), který byl spojený především s ,konkurenčním“ listem Pedagogické rozhledy (Kasper, 2018, s. 51). O těchto snahách budu tedy v práci referovat jako o tzv. př́hodovské reformě.

V článku bude nejdříve stručně nastíněn dobový kontext týkající se postavení katolicismu v mladé republice a podstata plánované reformy. $\mathrm{V}$ další části práce bude př̀edstavena analýza vybraných názorů publikovaných ve Věstníku v letech 1928-1935 a závěrem budou stručně shrnuty postoje Věstníku jako takového. Právě v roce 1928 vznikla v rámci Školy vysokých studií pedagogických reformní komise, které předsedal Václav Příhoda a která následujícího roku oficiálně předložila své návrhy na změny organizace školské soustavy. Od tohoto roku se na stránkách Věstníku stále častěji setkáváme s texty zabývajícími se danou reformou, at' už se jedná o krátké glosy, či podrobnější analýzy, které vycházejí na pokračování přes dvě či tři čísla časopisu.

Samotným Věstníkem se pravděpodobně podrobněji dosud nezabývala žádná odborná studie jinak je tomu u tématu školských reforem v daném období; na př́islušnou literaturu k tomuto tématu bude proto odkazováno např́íč celým textem.

\section{Historický kontext: katolicismus v první Československé republice}

Relevantním kontextem pro naše téma je i otázka postavení katolického náboženství v rámci relativně nově vzniklého státního útvaru. Zrod Československé republiky v rámci rozpadu rakousko-uherského mocnářství znamenal i oslabení vlivu katolické církve, která byla úzce provázána shabsburskou monarchií po mnoho staletí. Se změnou státnosti tedy př́mo souvisely také změny v náboženské oblasti, kde můžeme zaznamenat oslabení vlivu katolicismu vzájemně související i se vznikem jiných křest’anských církví. Katolicismus už nadále nebyl oficiálním náboženstvím státu, přestože většina křest’anů se ke katolicismu stále hlásila (Koucká a Papajík, 2001, s. 5-31).

Velký vliv na průběh těchto změn měl jistě i první československý prezident Tomáš Garrigue Masaryk (1850-1937), který zastával k náboženství sice pozitivní vztah, nicméně k církvím a ke katolické především - se naopak stavěl skepticky a preferoval osobní pojetí náboženství, at' už v rovině etické, či v rovině prožitku (Masaryk, 1947, s. 38). Přestože byl jako katolík vychován, nakonec se Masaryk hlásil spíše k protestantismu, přičemž neustále zdůrazňoval individuální a kritický př́stup k náboženským přesvědčením jako takovým a preferoval filosofický postoj k víře (Čapek, 1990, s. 290-294; Funda, 2001).

Tento odklon se projevil i na úrovni školství. Jednou ze zásadních změn bylo bezpochyby zavedení předmětu občanská výchova, který měl za cíl podpořit utváření těch nejzásadnějších morálních, společenských a občanských hodnot u žáků již od raných let:

Občanská výchova byla chápána jako výchova nadkonfesijní, výchova vedoucí ke světonázorové otevřenosti a respektujicí národní různorodost, která neměla bránit obecně 
humanistické koncepci člověka (...) vycházela z rozšíreného pozitivistického pohledu na etiku, který byl v české pedagogice rozvíjen od počátku 20. století. (Kasper, 2018, s. 28-29)

Tento krok neznamenal, že by se výuka náboženství či katolicismus ze státních škol vytratily. Představoval ale pohyb směrem k sekulární etice, která se sice z velké části překrývala s etikou teistickou, byla však jiné povahy. Tento posun byl veden $\mathrm{v}$ př́mém rozporu s katolickými konzervativními hodnotami a transcendentálním zakotvením etiky v náboženské doktríně. Dnes již považujeme za samozřejmé, že podobný pohled na etické a občanské vzdělávání je prosazován na oficiální úrovni i v současném školství; v období prvního československého státu se ale jednalo o relativně velkou změnu. ${ }^{2}$ Stát i většina českých učitelů se stavěla negativně k roli církví ve školství, ${ }^{3}$ a přestože byla výuka náboženských předmětů ponechána $v$ režii prríslušné instituce, stát měl právo dohlížet na tuto výuku i na dobrovolnou účast žáků při náboženských úkonech (účast byla ministerským výnosem definována jako nepovinná již v listopadu 1918).

Tato situace obecně nebyla částí československých katolíků přijímána bez výhrad, jak uvidíme níže u katolických učitelů či jak můžeme pozorovat např́iklad i u katolických autorů píšících v meziválečném období (Putna, 2010). Celkový posun katolicismu od oficiálního náboženství do spíše „opoziční“ roviny je pak silně znát i na stránkách Věstníku, kde se často setkáme s útočnou, povýšenou a někdy až bojovnou rétorikou:

Na katolického učitele dívala se veřejnost dosud namnoze jako na dobráčka, který jde sice cestou jinou než masy ostatního učitelstva, ale při tom naprosto nepokouši se, by uplatnil svůj názor mezi jinými. To nyní přestane (...) směr, kterým jdeme, uznávají dnes za správný již někteři z těch, kteři se stavěli kdysi ostře proti nám, a bude jich den ode dne př́bývat. (...) Nebát se. Nebojácným patři budoucnost! (Věstník 1931, IX, 9, s. 163)

\section{Tzv. př́ihodovská reforma a její cíle}

Diskutovaná reforma zahrnovala např́klad změny týkající se kurikula, struktury jednotlivých typů škol, vnitřního chodu vyučování a souvisela s reformou vzdělávání učitelů. Lze poukázat na dvojí rozměr této reformy: první se týkal změn ve školském systému a snahy jej učinit demokratičtějším, jednotným a užitečným pro potřeby doby; druhý se týkal realizace cílů tehdejšího reformě-pedagogického hnutí. Zatímco první desetiletí probíhalo spíše volnou až experimentální formou, druhé desetiletí bylo již programově vymezené a organizačně koherentní (Kasper a Kasperová, 2018, s. 162-163). Odborná literatura hovoří o tzv. příhodovské reformě, jelikož právě Václav Př́íhoda (1889-1979), vysokoškolský učitel

\footnotetext{
2 Takový postoj nalezneme v základním kurikulárním dokumentu, tzv. Bílé knize i v Rámcovém vzdělávacím programu pro gymnázia, který se př́mo věnuje výuce náboženské tematiky. Viz Národní program rozvoje vzdělávání v České republice: bilá kniha, 2001. Ministerstvo školství, mládeže a tělovýchovy, Praha: Ústav pro informace ve vzdělávání; Rámcový vzdělávací program pro gymnázia, 2007. Praha: VÚP.

${ }^{3}$ Přičemž tento proces nastal již na přelomu 19. a 20. století a souvisel mj. s implementací nových vědeckých poznatků do osnov či s odporem k habsburskému režimu. Situace se také lišila na českých, slovenských a německých školách, přičemž postoj prvně zmíněných byl především odmítající, zatímco slovenské a německé učitelstvo mělo k církvi postoj pozitivní či méně negativní (Kasper, 2018, s. 35-37).
} 
a odborný poradce na MŠANO, byl pravděpodobně nejvýraznějším iniciátorem těchto snah. Cíle změn byly silně ovlivněny kladným vztahem Př́hody a jeho kolegů k reformní pedagogice. Tzv. příhodovskou reformu řadíme především do onoho druhého období ${ }^{4}$

Mezi nejvýraznější programové body této reformy patřila jednotná vnitřně diferenciovaná škola, kratší časové sekvence při výuce jednotlivých předmětů, princip individualizace i principy spolupráce a demokratizace (žákům mělo být umožněno vydávání časopisu či účast ve školním parlamentu) či provázání obsahů jednotlivých předmětů (globalizace). K demokratizaci patřilo také podporování koedukace dívek a chlapců, kterou část veřejnosti přijímala s nechutí (Ibidem, s. 222-232).

Pedagogické smýšlení Václava Př́íhody bylo utvářeno českým pedagogickým prostředím, které bylo už od přelomu století formováno pozitivismem, scientismem a také diskuzí vyvolanou darwinismem (Kasper a Kasperová, 2017, s. 351-355). Př́ihoda zdůrazňuje nutnost přiblížit pedagogiku exaktním vědám, které mj. pracují s experimenty a usilují o dosažení objektivních výsledků. Velkou inspirací mu proto byly i snahy a metody behavioristů, kteří usilovali o ustanovení psychologie jakožto exaktně pojaté vědy (Kasper, 2014, s. 45-47).

Dalším výrazným vlivem byla americká pragmatická pedagogika. Příhoda byl během svého pobytu v USA v př́mém kontaktu s Johnem Deweyem, klíčovou postavou nejen pragmatické pedagogiky, ale i pragmatismu jako takového. Dewey se stavěl proti tradiční frontální a transmisivní metodě výuky a propagoval poměrně revoluční model vzdělávání založený mj. na demokratických ideálech, vedení k samostatnosti, praktických činnostem a jejich následné reflexi (Dewey, 1985, s. 26-27).

V československé pedagogice byl pozitivismus i americký přístup ke vzdělávání reflektován a oceňován již dř́ve (Úlehla, 1899), skrze Př́hodu se však americké ideály mohly prosadit na oficiální rovině v poměrně čiré podobě. Proponentem zdrženlivějšího, byt' také přijímajícího přístupu $\mathrm{k}$ pragmatismu v pedagogice byl Příhodův současník Otokar Chlup, který v této době vedl s Př́ihodou polemiky právě na toto téma (Kasper a Kasperová, 2019, s. 203).

Jakousi vlajkovou lodí mezi reformními školami byly měšt’anské a obecné školy ve Zlíně, které byly podporovány jak městem, tak Tomášem Batou (1876-1932) (Kasper, Kasperová, 2020). Autoři Věstníku se pak těmto školám poměrně obsáhle věnovali a snažili se na jejím př́ikladu ilustrovat obecné charakteristiky plánovaných změn.

\section{Reformy a Věstník katolického učitelstva}

V následujících podkapitolách bude nejprve stručně představen samotný Věstník $a$ následně budou na základě diskurzivní analýzy časopisu tematizovány postoje jeho autorů k reformním

\footnotetext{
${ }^{4}$ Snahy o reformy vzdělávání v meziválečném období byly mnohé a jejich klasifikace je nesnadná. Lze konstatovat, že „byly charakteristické individuálními pokusy jednotlivých učitelů-pokusníkư“ (Kasperová, 2018, s. 321), kteří čerpali inspiraci z mnoha různých zdrojů a snažili se své poznatky zužitkovat ve výuce. Více $\mathrm{k}$ tomuto tématu viz Ibidem, s. 311-435.
} 
snahám. Vzhledem k poměrně velkému množství materiálu se pokusím analyzovat postoje, které v listu zaznívají nejčastěji či jsou prezentovány jako ty nejzávažnější.

S ohledem na diskuze vedené ve Věstníku lze konstatovat, že na konci dvacátých let se přispěvatelé vyjadřovali $\mathrm{k}$ reformě spíše povšechně, se začátkem let třicátých bylo stále více místa věnováno popisu (jak reformy samotné, tak škol, které zaváděly nové postupy s ní související) a obsáhlejšímu zhodnocení reformních snah. Z analýzy článků také vyplývá, že během celého časového období let 1928-1935 převažoval negativní náhled u téměř všech přispěvatelů časopisu. Níže se pokusím nejprve shrnout obecné postoje autorů a na základě konkrétních vyjádření vybrat úryvky z textů časopisu, které účelně reprezentují názory autorů. Tyto postoje budou vzhledem ke své převážně negativní povaze rozděleny na výtky ideologické a výtky odborně věcné.

\subsection{Věstník katolického učitelstva jakožto hlas spolku}

Věstník byl vydáván Řišským svazem katolického učitelstva československého, který zastupoval zájmy a názory katolické části učitelů. Postavení těchto učitelů i katolíků jako takových je ve Věstníku průběžně připomínáno a reflektováno; např́íklad v roce 1929 při komentáři týkajícím se sedmi set účastníků sjezdu českých katolických učitelů: „Uvážíme-li, jakému teroru jsou až dosud vystaveni naši členové a členky v Čechách, můžeme být na tuto velkou účast hrdi.“ (Věstník 1929, VII, 20). Časopisy reprezentující mnoho rozdílných skupin učitelů (např. učitele moravské, slovenské, socialisticky smýšlející apod.) byly obecně součástí tehdejšího profesního života (Kasper, 2018, s. 52-54).

Věstník byl vydáván v Přerově a obracel se především na učitele české, resp. moravské. Často ale autoři Věstníku referovali také o problémech a událostech týkajících se katolických učitelů slovenských, polských či německých. Řišský svaz také pořádal sjezdy učitelů, přičemž počet účastníků se pohyboval v úrovni několika set jedinců (Věstník 1928, VII, 1 a 1929, VII, 20).

Jak vyplyne v následující kapitole, př́spěvky publikované ve Věstníku se také často vyznačovaly afinitou ke konzervatismu. Ten se neprojevuje jen v rovině náboženské (odklon od tradičního katolického pojetí světa personifikovaný T. G. Masarykem), ale také obecně $\mathrm{v}$ rovině postoje ke změnám. Konzervatismus v pedagogice se obecně vyznačuje tendencí být skeptický k vzdělávací reformě a k ambiciózním projektům změny sociálních institucí vůbec. „Vytvořit fungující sociální instituce je těžké, ale rozvrátit je lze poměrně snadno (...) nové neznamená automaticky lepší.“ (Dvořák, Starý a Urbánek, 2015, s. 45). Jak bude patrné na následujících řádcích, tato konzervativní pozice je jedním z prvků, který přispěvatele Věstníku spojoval.

\subsection{Obecný postoj k reformě}

$\mathrm{Na}$ listech časopisu převažoval jednoznačně negativní, nedůvěřivý až hostilní postoj $\mathrm{k}$ reformě. Ta byla vnímána jako uspěchaná, nezodpovědná a příliš rozsáhlá. Neustále byl také zdůrazňován její moderní a liberální charakter; autoři článků tak proponenty reforem vnímají spíše jako jedince, kteří podlehli kouzlu nových zahraničních metod, které jsou sice 
líbivé, ale postrádají historické a kulturní zakotvení, které je pro vzdělávací proces nezbytné. Některé z těchto názorů lze nalézt už v článku z roku 1927, který předznamenává budoucí postoj mnoha dalších článků:

Učitelstvo tak se během doby „zakouslo“ do „,pokroku“, že nevidělo před sebou ničeho jiného než toto kouzelné slovo, které sice několika málo jednotlivcům z jeho řad prospělo, ale jinak jemu nepřineslo nic jiného než ohromnou škodu. (...) Jini hleděli na př́slovečný český „pokrok“ jen jako na pouhou módu, která vládne dnes, a proto třeba jíti nějaký čas s ní, př́padně považovali pokrok jen za jakýsi druh sportu, učitelstvo však v něm vidělo cíl svého života. (...) Učitelstvu nezbude nic jiného, než pridati se k nám. Budoucnost patři organisacím založených na vyššich ideách, na ideách katolicismu, jest jen třeba, aby tyto vyvinuly více agilnosti, by se učinily známějšimi. (Věstník 1927 V, 4, s. 88-89)

Tento úryvek nastiňuje i pozdější názory vyslovené ve Věstníku: zaprvé kritickým tónem spojeným ani ne tak s jakýmikoliv reformami, ale spíše s jejich mírou; zadruhé odkazem na dlouhou tradici a posvátnost katolicismu jakožto nutného základu pro celkové vidění světa a zatřetí i snahou nabídnout jinou cestu než tu, která přichází s reformami.

Mezi autory časopisu často vynikal Antonín Krejčír, který se k návrhům reformy vyjadřoval průběžně už od konce dvacátých let dvacátého století, kdy vyzýval k opatrnosti při tak závažné činnosti, jako je reforma školského systému. Krejčíř rovněž varoval před př́lišným podléháním pedagogickým trendům a požadavkům moderní doby (Věstník 1929, VII, 13, s. 227-228).

Reformní hnutí bylo na stránkách listu tedy silně spojováno s časovostí, která nemůže v budoucnu obstát, zatímco ideje tradiční, katolické byly prezentovány jako ty věčné; tedy ty, ke kterým bude nakonec nutné se vrátit. „Kristův idealismus“, jenž obstojí podle autorů zkoušky času, byl pak stavěn oproti mladým a nevyzrálým myšlenkovým směrům, které měli zastávat tvůrci reforem. Mezi proudy spojovanými s touto novou „praktickou“ cestou byl zmiňován pozitivismus, materialismus, marxismus či socialismus. Často se lze setkat i s kritikou jednostranné fascinace reformátorů Spojenými státy, přičemž na mysli mají autoři s největší pravděpodobností právě ,praktickou“ orientaci pragmatické pedagogiky (Věstník 1929, VII, 13, s. 28; Věstník 1929, VII, 20, s. 355).

Pomyslný boj mezi „,pokrokáři“ a Věstnikem byl tak na stránkách listu často pojímán nejen jako spor odborný, ale jako spor hodnotový: souboj nových, mělkých a pseudovědeckých ideálů reformátorů oproti tradičním katolickým hodnotám, souboj nevíry proti víre. Takové pojetí pak ještě přidává váhy a podporuje ostrou rétoriku časopisu:

Učitel opravdu katolický musí zakoušeti mnoho úštěpků, výsměšků od „pokrokových“ kolegů, kteři o sobě ř́kají, že jsou osvětáři, světlonoši apod, nazývajice nás „,tmáři “ (...) [musíme] se přičiňovati ze všech sil, aby postavena byla mohutná hráz proti expansi nevěry, by takto nezapustila kořeny do rodin křest’anských, nerozhlodala je v základech a nezadusila. (Věstník 1931, V, 11, s. 184) 
Reformy byly také prezentovány jako nepromyšlené hrubé náplasti na problémy, které nemohou fungovat ze své podstaty:

Mluví se tudǐz zatím nejvíce o metodách a nejvice pokusů dělá se v tomto směru. Dělají je jednotlivci, zkoušejí je v pokusných školách, jichž je letos patnáct. Jsou horlivci, jimž se zdá, že by měly býti všude. Horlivost trochu zbytečná! Nemůžeme přece ze všsech dětí udělat pokusný materiál! (Věstník 1931, IX, 10, s. 183-184)

\subsection{Ideologické výtky: „Kulturní diktatura doc. Př́íhody“6}

$\mathrm{Na}$ počátku roku 1931 shrnul Antonín Krejčíř hlavní novinky, které byly praktikovány ve vzdělávání na měšt’anské škole ve Zlíně. Jako změny uvedl jednak důraz na samostatnou práci, diferenciaci a rozdílný přístup k různě nadaným žákům. Vzápětí však došlo ke zhodnocení těchto bodů. Podle Krejčciřre se nejednalo o novinky, ale o staré postupy, které byly známé již za Komenského a kterým byl pouze dodán nový kabát. Důraz na samostatnost žáků byl podle Krejčíře nevyhnutelně spojený s rizikem plýtvání drahocenným časem a testy prezentované zlínskou školou nejsou prosté zavádějících otázek. A přestože se vlastně nejednalo o výrazné novinky, dostalo se jim ,zdůraznění a reklamy, jíž nechybí jistý rys amerikanismu. A zdá se, že jejich interpreti dali se okouzlit Amerikou poněkud přes nutnou míru. Musíme přece chtít, aby reforma vycházela z naší půdy, aby národní škola zůstala i nadále naší školou“ (Věstník 1931, IX, 10, s. 184).

I globální metoda byla týmž autorem přijata velmi kriticky s odkazem na dříve publikovaný článek „O metodu elementárního čtení“ v Pedagogických rozhledech. Přestože byla podle Krejčíře podána rozumná kritika této metody, ,zdá se, že nová metoda stává se zhýčkaným děckem, na něž se nesmí nikdo křivě podívat a jehož všechny vlastnosti - dobré i zlé, jsou pokládány za ohromující, nedostižitelné.“ Přestože hledání nových metod není samo o sobě špatné, neměla by se podle autora u odborné i učitelské veřejnosti chválit inovace, která je objektivně nedostatečná (Věstník 1933, XII, 8, s. 97).

V březnovém čísle roku 1931 Věstník shrnul a zhodnotil zásadní nedostatky nové reformy. Ta měla být postavena na metodách kvantitativní psychologie, která měří duševní jevy, tedy něco exaktně neměřitelného. Pedagogika postavená na základech psychologie je tedy podle závěrů Věstniku ,pavědou“, nebot' pedagogika je ve skutečnosti vědou ve smyslu filosofickém, tedy vědou „spekulativní, duchovou“ a nelze v ní tedy uplatňovat rádoby exaktní pokusy a metody, jak činili tehdejší reformátoři. „Název Př́íhodovy poslední knihy Racionalisace školství zůstane výrazem jen dobře míněného prání. Realisovatelným programem nebude nikdy“ (Věstník 1931, IX, 13, s. 224-226). V článku jsou vyjmenovány další výtky jako např́íklad nedůvěryhodnost inteligenčních testů, roztříštěnost amerického školství (které mělo být pro reformisty vzorem), nákladné změny na školách, na které stejně nebude dostatek prostředků aj. (Ibidem, s. 226). Hlavními výtkami však zůstalo výše uvedené zpochybnění psychologie a na ní postavené pedagogiky: „Duševnost je totalita, kvantitativně neměřitelná, at’ už si ř́ká Thorndike a Claparéd, co chce“ (Věstník 1930, IX, 1, s. 3). 
Negativně bylo hodnoceno i přijetí občanské výchovy, nebot' ta by měla být spíše průřrezovou látkou mnoha předmětů. Podobně je tomu i u omezení náboženské výchovy, které může znamenat úpadek duševního života i zdraví mládeže:

Snad už zvykáme na přestupky proti mravopočestnosti, jsme lhostejní, čteme-li, že se člověk oběsil, zastřelil, nebo skočil pod vlak. Jaký rozvrat zachvátil mladá srdce, když misto odvahy k práci jsou proniknuta nechutí k životu! Lékařri pro nervové choroby v Berlíně varují, aby byla škola bez náboženství, aby bezvěrectvi bylo pěstováno v útlých dušich. (...) Myšlenka, že bytost nad námi vede a ř́dí náš osud, že dočasné strasti nahradí nám stálou odměnou, je světlo do temnot a pustin zoufalství a trýzní duševních. (Věstník 1931, IX, 13, s. 247)

Omezení tradice a důrazu na spirituální rozvoj ve prospěch potřeb doby - nebot' tak byla tzv. př́ihodovská reforma také chápána - pak může upozadit hlubší otázky lidské existence. Škola má být vnímána nejen jako průprava na profesní a občanský život, ale především na poznání lidské přirozenosti. Nové pojetí vzdělávání pak ohrožuje právě tyto „hlubši““ stránky výchovného a filosofického aspektu školy (Věstník 1933, XI, 13, s. 208-210). Tyto hlubší a zásadní otázky lidského údělu pak podle autorů časopisu byly a jsou úzce spojeny s otázkami náboženskými:

Člověk neni bytost jenom hmotná, ale také duchovni a jeho duchovni určenížádá po každém člověku, aby svưj životní názor budoval jen z kvádrů pravé kultury, a ta u nás spočivá na křestanství a jest jím skrz naskrz proniknuta, a tak, má-li světový názor dnešních lidí odpovidat kulturním požadavkưm dněsniho světa, pak (...) musí být [v osnovách] doplněn duchem náboženství, v němž ditě je vychováváno od malička v rodině. (Věstník 1934, XIII, 4, s. 57)

Na přelomu roku 1934 a 1935 vydal Antonín Krejčíř pokračující článek „Současný stav pedagogiky“ (Věstník 1934-1935, XIII, s. 7-9), který pojednával o tehdejším vnímání pedagogiky, ale přinesl také shrnutí kritiky namířené proti reformě. $V$ jejím rámci nicméně zazněly již vyřčené body jako „pseudovědecký“ charakter Př́íhodova chápání pedagogiky, převratnost změn a nenavázání na tradici (i ve smyslu náboženském) či důraz na rozvoj intelektu, ale zanedbání výchovných a hodnotových aspekti̊ vzdělávání (Věstník 1934, XIII, 8, s. 110). Následující články v roce 1935 se pak věnují už jen vybraným jednotlivostem spojeným s reformou.

\subsection{Odborně věcné výtky: „Hospodářskou stránku nelze přehlížeti““}

Věstník také poukazoval na materiální problémy, které by mohla reforma měšt'anské školy přinést. Autoři konstatují, že zvýšení nákladů pro obce bylo pocitováno hlavně na venkovských školách, přičemž venkovské obyvatelstvo podle Věstníku pozitivně nepřijímá ani prodloužení školní docházky do 15 let (Věstník 1931, IX, 13, s. 246). „Myslím, že bude lépe, když (...) [osnovy] zůstanou na reálné půdě současného našeho rozvoje školského a našich poměrů sociálních a hospodářských (vždyt' i škola chtíc-nechtíc jest jejich odrazem)“ 
(Věstník 1931, IX, 14, s. 264). Ve školách bude také nutno zajistit pro žáky více pomůcek, což bylo potenciálně problematické zhlediska financování. Učivo, jak bylo prezentováno reformátory, může působit na žáky roztříštěně a hrozí riziko přetížení žáků z nižších ročníků (Věstnikk 1931, IX, 15, s. 286).

Špatně byla přijímána i sama osobnost Václava Příhody, jehož role v reformním snažení byla nahlížena jako př́liš významná - a místo toho, aby jako předseda komise pro sestavení osnov spíše usměrňoval odbornou diskuzi, diktoval téměř celý plán budoucích osnov. Osnovy samotné byly potom vnímány jako př́liš vágní, a nemohou tedy představovat solidní a nadčasový podklad pro výuku (Věstník 1931, IX, 14, s. 263). Příhoda pak měl také získávat mnoho zastánců; jsou to „učitelé starší, hlavně obecnoškolští (...) jsou orientováni anglosasky a socialisticky, vyznačují se předválečnou nechutí ke spekulativní filosofii a vyznávají starý positivistický empirism“ (Věstník 1931, IX, 16, s. 303). Pozitivně naopak Věstník hovořil o Otokaru Chlupovi a jeho pohledu na reformy. Chlup byl prezentován jako stř́zilivější, kritičtější myslitel, který se nevyznačoval takovým obdivem k americké pedagogice (Ibidem). Př́hodovi bylo také vytýkáno údajné pokrytectví: na jednu stranu se pokoušel prosadit individuální př́stup ve výuce, který má být orientovaný na dítě, a na stranu druhou se snažil o objektivizaci hodnocení žáků, hlavně v podobě jednotných testů. Takový př́ístup měl ignorovat například fakt, že některým žákům vyhovuje zkoušení ústní nebo že v některých předmětech je mnohem těžši znalosti hodnotit objektivně (Věstník 1932, XI, 2, s. 22-23.; Věstník 1934 XII, 19, s. 47-49).

\section{Závěr}

Lze konstatovat, že hlasy zaznívající ve Věstniku k tzv. příhodovské reformě jsou v průběhu let 1928-1935 převážně negativní. Všichni přispěvatelé nebyli zcela odmítaví ke konkrétním prvkům reformy ve školství, ale stavěli se ostře proti jakýmkoli změnám zásadního charakteru. Rétorika listu je $\mathrm{z}$ dnešního pohledu velmi ostrá, místy až agresivní a autoři se stavěli proti téměř jakýmkoli změnám, které jsou spojeny se jménem Václava Př́hody. Ten byl vnímán jako „pseudovědec“, „filoamerikán“ a radikál, který nemá pochopení pro specifika českého prostředí. Př́hodova snaha školství „racionalizovat“ byla Věstníkem vnímána jako neracionální, přehnaná a nebezpečná, nebot' vytrhává žáky z tradic a historických kontextů a snaží se je vést v duchu liberálního smýšlení.

Postoj Věstníku k reformě lze zařadit i do širší perspektivy: první Československá republika se od svého vzniku profilovala jako liberální západní demokracie, přičemž realizace idejí pragmatické pedagogiky byly jen jednou z manifestací této profilace. Katolicismus, spojený $\mathrm{s}$ předchozím státním zřízením, je nepřátelský či alespoň skeptický k přijímání liberálních hodnot a př́stupů obecně. Na poli školství můžeme tento jev pozorovat mj. právě na rovině postoje Věstniku k tzv. prŕíhodovské reformě. V ještě širší rovině pak můžeme stanovisko listu zařadit ke konzervativním proudům $\mathrm{v}$ dějinách pedagogického myšlení.

Můžeme také poukázat na fakt, že z katolických pozic zaznívá podobná kritika nových modelů vzdělávání i v jiných zemích. S odstupem několika desetiletí například Christopher Dawson ve svém díle Krize západní vzdělanosti (1961) kritizuje snahu vyvázat systém 
vzdělávání z křest’anských, katolických kořenů a jako konkrétní viníky označuje mj. právě představitele pragmatické pedagogiky: „[Dewey] byl přesvědčen, že morálka je zásadně sociální a pragmatické povahy a že by se mělo odporovat každému pokusu podřídit vzdělání transcendentálním hodnotám nebo dogmatům." (Dawson, 1991, s. 14; 59).

Poměrně zajímavé také je, že častá výtka týkající se vágnosti a obecnosti cílů výuky, kterou autoři Věstníku adresují směrem ke změnám ve školství, nemusí nutně souviset pouze s tzv. př́hodovskou reformou. Do jisté míry by se jistě dala vztáhnout i na Rámcové vzdélávací programy, které jsou v současnosti základem pro Školské vzdělávací programy, které jsou pak př́mými podklady pro výuku ve třídách. RVP často vyvolávají otázku, co přesně má být předmětem vyučování či jak v hodinách propojit klíčové kompetence s obsahem učiva. Lze tedy uzavřít, že problém vágnosti při realizaci jakékoli školské politiky týkající se zásadních kurikulárních změn je pravděpodobně něčím, co bytostně souvisí s povahou těchto změn.

\section{Primární zdroje}

Věstník katolického učitelstva československého: orgán Řišského svazu katolického učitelstva československého, 1923-1941. Praha: Svaz křest’anského učitelstva.

\section{Literatura}

ČAPEK, Karel, 1990. Hovory s T. G. Masarykem. Praha: Československý spisovatel. ISBN 80-202-0170-X.

DAWSON, Christopher., 1991. Krize západní vzdělanosti. Praha: Státní pedagogické nakladatelství. ISBN 80-04-25392-X.

DEWEY, John, 1985. The middle works, 1899-1924. Volume 9: Democracy and Education. Carbondale; Edwardsville: Southern Illinois University Press. ISBN 0809307537.

DVOŘÁK, Dominik, STARÝ, Karel a URBÁNEK, Petr, 2015. Škola v globální době: proměny pěti českých základních škol. Praha: Nakladatelství Karolinum. ISBN 978-80-2462977-3.

FUNDA, Otakar Antoň, 2001. Náboženství - téma, které Masaryk odkázal české filosofii. In: T. G. Masaryk, idea demokracie a současné evropanství: sborník mezinárodní vědecké konference konané v Praze 2.- 4. března. 2. díl. Praha: Filosofia. ISBN 80-7007-145-1.

KASPER, Tomáš a KASPEROVÁ, Dana, 2019. Development and Focus of Czech Pädagogik in the Late 19th and Early 20th Centuries. In: KUDLÁČOVÁ, Blanka a RAJSKÝ, Andrej. Education and "Pädagogik": philosophical and historical reflections: (Central, Southern and South-Eastern Europe). Bratislava: VEDA. ISBN 978-80-224-1717-4.

KASPER, Tomáš a KASPEROVÁ, Dana, 2017. Exactness and Czech pedagogy at the break of the 19th and 20th Century. History of Education \& Children's Literature. Macerata: Università di Macerata, roč. 13, č. 2, s. 343-358. ISSN 1971-1093.

KASPER, Tomáš, KASPEROVÁ, Dana a PÁNKOVÁ, Markéta, eds., 2018. „Národni““ školství za první Československé republiky, Praha: Academia: Národní pedagogické muzeum a knihovna J. A. Komenského. ISBN 978-80-86935-41-6. 
KASPER, Tomáš a KASPEROVÁ, Dana, 2020. „Nová škola“ v meziválečném Československu ve Zlíně: ideje, aktéři, místa. Praha: Academia. ISBN 978-80-200-3091-7.

KASPER, Tomáš, 2014. Teorie výchovy včeské meziválečné diskuzi. In: JEDLIČKA, Richard. Teorie výchovy - tradice, současnost, perspektivy. Praha: Karolinum. ISBN 978-80246-2412-9.

KASPEROVÁ, Dana, 2018. Československá obec učitelská v kontextu reformy vzdělávání učitelů (ŠVSP) a reformy školy. Praha: Academia. ISBN 978-80-200-2860-0.

KOUCKÁ, Ivana a PAPAJÍK, David, 2001. Politický katolicismus v nástupnických státech Rakousko-Uherské monarchie $v$ letech 1918-1938. Olomouc: Univerzita Palackého. ISBN 80-244-0372-2.

MASARYK, Tomáš Garrigue, 1947. V boji o náboženství. Praha: Čin.

Národni program rozvoje vzdélávání v České republice: bílá kniha, 2001. Ministerstvo školství, mládeže a tělovýchovy Praha: Ústav pro informace ve vzdělávání. ISBN 80-2110372-8.

PUTNA, Martin C., 2010. Česká katolická literatura v kontextech: 1918-1945. Praha: Torst. ISBN 978-80-7215-391-6.

Rámcový vzdèlávaci program pro gymnázia, 2007. Praha: VÚP. ISBN 978-80-87000-11-3. ÚLEHLA, Josef, 1899. Listy paedagogické. V Praze: Dědictví Komenského. 